\title{
Chinese Soldiers as Prisoners in Korea: Ideological Enigma Bruce Jacobs
}

The handling and dispositions of enemy prisoners of war, as a national responsibility, established itself on the front-burner of America's attention span, as a crucial sidebar to the war in Iraq. Controversy has, rightly or wrongly, also characterized American views of the military prison facility at Guantanamo Navy Base in Cuba as a detention center. The widely-publicized events at the U.S.-run Abu Ghraib prison in Baghdad focused worldwide attention on how we appeared to be carrying out the responsibility which evolves upon a country with prisoners in its custody.

During 2005 the Army Combat Studies Institute took a hard look at the subject of "detainee doctrine and experience" noting in the introduction that, "the perception of just treatment held by citizens of our nation and, to a great extent the world at large, have been and are being shaped by the actions of the US Army, both in the commission of detainee treatment but also, and more importantly, in the way the Army addresses its institutional shortcomings.”

In tracing the history of this sometimes seriously misunderstood subject the author of The Road to Abu Ghraib ${ }^{1}$ revisits the U.S. experience in the prisoner-of-war issues of the Korean War. Mismanagement of prisoners taken by United Nations Command troops in the war should be looked at in the light of the reminder by the author of the study that, "the surprise and rapidity of the North Korean invasion of South Korea forestalled any effort to plan for the care of EPWs ${ }^{2}$ on the scale necessary." 3 In this essay we will explore some of the unusual circumstances, particularly those of the Chinese prisoners of war, which would lead to subsequent and perhaps inevitable allegations of prisoner abuse in the UNC prison compounds.

The army's study followed the appearance of a novel, War Trash ${ }^{4}$ - which explores the subject through the eyes of a fictional character who offers an exCommunist Chinese soldier's bird's eye view of little-known history that - in one reviewer's words - "most of us have forgotten or never knew about, to begin with."

The Road to Abu Ghraib and - to a far greater degree, War Trash - renewed the writer's interest in a subject first explored - and last given any serious thought to - in connection with a research project at the Army War College in 1971-1972.

War Trash reminds us all too well of a time when national ambitions, ideological differences and cultural complexities clashed so violently that even now, half a century

\footnotetext{
The author retired from army service as a major general in 1985. He is a graduate of the U.S. Army War College and in 1978-79 earned a Master's degree in diplomatic history at Georgetown University. He is the author of books and articles on military history; his earliest publication was Korea's Heroes in 1961.

1 “The Road to Abu Ghraib: U.S. Army Detainee Doctrine and Experience,” Major James F. Gebhardt, USA (Ret), Fort Leavenworth, KS: Combat Studies Institute, 2005. (Hereafter, Abu Ghraib).

${ }^{2}$ The acronym "EPW" for enemy prisoner of war came into widespread use in the U.S. military in the Persian Gulf War, 1991. In this essay the more familiar "POW" will be used in discussing prisoners of war.

${ }^{3}$ Abu Ghraib, 15.

${ }^{4}$ Ha Jin War Trash. New York: Pantheon Books, 2004.
} 
later, the subject still inspires a gamut of emotions. Being inspired by fiction to re-open the study of historical actuality is perhaps skating on thin ice. War Trash, to paraphrase a talk-show program which recently discussed trends in non-fiction which turn out to be fiction, is an example of fiction that reads like non-fiction. Unusual in fiction the author provides a respectable bibliography of the literature on the subject of the Korean War.

It is fortuitous that much of the content of War Trash is verified by the increasing emergence of serious studies on the subject of the Chinese Communist intervention in the Korean War, the impact of continued U.S. efforts to support Chiang Kai-shek and Nationalist China and how - in a sense - Chinese soldiers who became prisoners of the United Nations Command, faced the additional burden of having to make the decision, under pressure, as to where and how their future lives would be spent. Their fate even beyond incarceration was to become part of a struggle which extended combat beyond the parameters of the battlefield.

The case for our consideration of War Trash as a pathway to helping us understand a complex and controversial subtext to the Korean War of 1950-53 is expressed in a few succinct words from a book review by Robert D. Kaplan, distinguished author of Warrior Politics. Kaplan says: “This is more than a novel. It's an historical document about a forgotten part of a forgotten war. No historian could bring to light this tale of interminable loneliness and suffering about Chinese prisoners during the Korean War as well as Ha Jin has.”

In this prize-winning ${ }^{5}$ tour de force the author of War Trash provides an account which contains eerie resemblances to the details of the reality. The story which emerges from the reality is no less gripping than the fiction. It provides a rare view of an aspect of the POW experience in the Korean War, as seen through Chinese eyes. ${ }^{6}$ Interestingly, War Trash maintains significant consistency with the true-life story of Zhang Da, a Chinese veteran of the "People's Volunteer Army" who gave a rare and candid interview in 2000 to John Pomfret, a Washington Post foreign correspondent/Beijing bureau chief and a well-respected "New China Hand".

Ha Jin's central character, Yu Yuan, is a junior officer, a graduate of the Chinese Nationalist Whampoa (Huangpu) ${ }^{8}$ Military Academy, who has joined the People's Liberation Army but has not yet made the commitment to join the Communist Party. He is regarded with some suspicion by many of his new companions despite his "respect" for Communist accomplishments. He is given an administrative job in the headquarters of the ill-fated 180th Division of the 60th Army, Chinese Peoples Volunteer Army. In the Chinese "5th Phase Offensive" launched April 20, 1951, the 180th Division met with a

\footnotetext{
${ }^{5}$ War Trash earned the author the 2005 PEN/Faulkner award for literature. He first earned the same honor in 2002 for Waiting, the story of a medical officer in the PLA.

${ }^{6}$ War Trash, blurb on dusk jacket, "Advance Praise for War Trash”.

${ }^{7}$ In "Chinese Question Role in Korean War," by John Pomfret, Washington Post Foreign Service, in the Washington Post, Sunday, October 29, 2000 ; Page A32.

${ }^{8}$ Historians and journalists do not all agree on English language references to place names in China. There is no better example than in the instance of China's capital city - formerly and for many years "Peking" but renamed as Peiping in English under the Wade-Giles transliteration system which prevailed for many years. Around the time of the Chinese Communist ascendancy in China the pinyin system came into favor and the capital (which had been renamed Beiping after WWII) was changed to Beijing. But many Republic of China (Taiwan) maps and English texts continue to use the Wade-Giles names. In this text names for the most part are used as commonly used in the Korean War era (Wade-Giles) with Pinyin names provided in parentheses, for example: Whampoa (Huangpu) and Tientsin (Tianjin).
} 
dismal fate when it was severely mauled by the U.S. 24th Infantry Division. It suffered many combat casualties and an estimated 5,000 taken prisoner.

Zhang Da, the real life soldier, was a company grade officer in the 180th Division. Like the fictional Yu Yuan he was wounded and nearly lost a leg to a U.S. Army surgeon's scalpel; and like Yu Yuan he was among the Chinese Communist soldiers who chose repatriation and were rewarded by being branded as traitors for not having fought to the death.

Author Ha Jin, 50, currently lives in the Boston area and is a professor of English at Boston University. He left China in 1985 to attend Brandeis University. His interest in the Korean War - particularly in the plight of the Chinese taken prisoner - was whetted by his own experiences as a youthful member of the People's Liberation Army. The son of an army officer (who served in the Korean War), he says that he joined the service to get away from home since it was during the period of the Cultural Revolution and his school was closed down. The book's title has no special significance but, says the author is a play on the American expression "white trash”. He acknowledges that War Trash is not likely to see the light of print in his native China.

Although ultimately and adamantly supportive of the "return home" faction of the Chinese POW population, his central character Yu Yuan, allows that, “to be fair, I didn't feel that our captors treated us very badly. At least we were sheltered and had food. Most of the wounded prisoners had access to medical treatment, though conditions still had room for improvement... On the whole I had to admit that the Americans were generous, at least materially."

His own peacetime PLA service was in the northeast where China's border abutted the then-Soviet Union. His published interviews are somewhat vague as to what inspired his interest in probing the fate of Chinese prisoners of war in Korea. He does say that from talking to fellow soldiers and veterans he learned that "most soldiers were more afraid of captivity than death..." Whatever his motivation he succeeds in directing our interest to an aspect of the war given scant attention by U.S. historians. From our side there has been, quite naturally, far more attention given to the mistreatment of U.S. servicemen held by the Chinese and North Koreans. Few who survived the Communistrun POW camps would concur in Ha Jin's comment (or, rather, Yu Yuan's) that, "History has shown that the Chinese always treat their enemies more leniently than their own people.”

But setting that subject aside if - as many Americans believe, the Korean War is a forgotten war, even more forgotten are the strange circumstances surrounding the handling of approximately 21,700 Chinese prisoners of war.

The chain of events critical to the fate of the Chinese prisoners began in midOctober 1950 with the PRC intervention in the Korean War. The conflict would come to an end July 27, 1953 when an armistice was signed and 6,000 Chinese soldiers were immediately released to go back to China. ${ }^{9}$

But the books on this matter would not be closed until January 20, 1954 - nearly six months after the signing of the armistice - when the vanguard of 14,066 Chinese soldiers who rejected repatriation to the People's Republic of China - crossed the southern boundary of the demilitarized zone (DMZ) near Chorwon. They were greeted by

\footnotetext{
${ }^{9}$ In addition to those already released at the time of Operation Little Switch when the sides exchanged sick and wounded prisoners.
} 
representatives of the United Nations Command and the Nationalist Government of the Republic of China by then on the island of Formosa (Taiwan). ${ }^{10}$

The ex-POWs would fill 540 U.S. Army 2-1/2 ton trucks for the first leg of the odyssey. After a brief halt for processing at Ascom City - the U.S.-built logistical center midway between Seoul and Inch'on, the newly-freed POWs boarded a small fleet of U.S. Navy World War II-era LSTs (landing ships, tank). Escorted by U.S. combat naval vessels the flotilla headed for Taiwan. On-board security was provided, fittingly, by leathernecks from the U.S. 4th Marine Regiment, the old "China Marines" of the preWWII years. They reached Keelung the port city northeast of Taipei on January 25. A final contingent arrived the next day. The saga of the Chinese POW struggle had reached its resolution if not its conclusion.

In the realignment of international friendships and alliances which marked the onset of the Cold War, at least one old friendship was now history.

\section{When Old Friends Become Enemies: Historical Background}

China’s long war with Japan spanned the period from September 18, 1931 (the Manchuria Incident) to September 3, 1945 (when Japan surrendered to the U.S. and its allies which included China). In World War II the U.S. had been a staunch ally of China and maintained a steady stream of logistical support to Chiang Kai-shek and his Nationalist government.

With reference to these many years of conflict, a Chinese historian has written, "the United States moved from sympathy to assistance and cooperation with China....Such assistance which can never be forgotten has left a glorious page in the annals of the twentieth century."11

But this "glorious page" would abruptly come to an end five years later when Chinese armies, by then under the orders of Mao Tse-tung's Communist regime, were sent into Korea to fight against U.S./UN forces which had come to the aid of South Korea following the invasion of the North Korean People's Army (NKPA) on June 25, 1950.

At the time of the cessation of WWII hostilities the bulk of Generalissimo Chiang Kai-shek's army was situated in southwestern China. The U.S. wartime contributions of resources to China had been encouraged by both Presidents Roosevelt and Truman in the hope that a stabilized China would emerge from the war as a dominant power in Asia and an ally of the U.S.

The U.S. strategy in 1946-47 was support for a reformed Nationalist China and nuanced opposition to the Chinese Communist movement led by Mao. Efforts to reconcile the rival movements were marked by the dispatch of General George C. Marshall to China as the president's personal representative. Marshall's hopeless task was to achieve a political rapprochement between Chiang and the burgeoning Chinese Communist presence.

But the joust for control of China was not destined to be settled as the Americans hoped. The clash between the rival factions was soon a full-blown Civil War and the winds of destiny ultimately favored Mao. A dispirited and disappointed Marshall left

\footnotetext{
10 "The Handling of Prisoners of War during the Korean War," Department of the Army, Pacific, Military History Office Headquarters, June, 1960, 96. (Hereafter, Handling POWs).

${ }^{11}$ Hsu Long-hsuen and Chang Ming-kai, compilers; Wen Ha-hsiung, translator, History of The SinoJapanese War (1937-1945). Taipei, Taiwan (Republic of China): Chung Wu Publishing Co., 1985 (1971), 556.
} 
China at the end of 1946 and the bad taste of his China mission must have lingered even as he assumed the role of Secretary of State on January 7, 1947.

On May 1, 1946 the U.S. closed out its wartime military headquarters - U.S. Forces, China Theater - which had been created originally under Major General Claire L. Chennault in October, $1944^{12}$ - to "advise and assist the Generalissimo [Chiang Kaishek] in the conduct of military operations against the Japanese." Established at Chungking, the headquarters was moved to Shanghai on October 14, 1945. Soon after its establishment, the command was turned over to Major General (later Lieutenant General) Albert C. Wedemeyer.

Wedemeyer soon shared Stilwell's disillusionment. He quickly recognized and "repeatedly warned"13 that the accomplishment of Chiang's goals were beyond his means without an enormous contribution of U.S. resources.

Tsingtao became the last U.S. garrison in China on September 1, 1947 with the departure of the rear echelon of the 1st Marine Division from Tientsin. It was manned by two battalions of Marines whose role became increasingly tenuous. During that period, "the Fighting between the Nationalists and Communists grew steadily more violent and bitter, and the possibility of Marine involvement was always present."14

To an experienced American soldier then on the scene it was evident, by December 1948, which the denouement was at hand. Major General David Barr, USA, ${ }^{15}$ observed that:

"Only a policy of unlimited United States aid including the immediate employment of United States armed forces to block the southern advance of the Communists, which I emphatically do not recommend (emphasis added), would enable the Nationalist Government to maintain a foothold in southern China against a determined Communist advance...The complete defeat of the Nationalist Army ...is inevitable."16

\section{The People's Liberation Army (PLA)}

To capture the enemy's army is better than to destroy it; to take intact a battalion, a company or a five-man squad is better than to destroy them.

- Sun Tzu, The Art of War $^{17}$

The predictable collapse of Chiang's army came about in the fall-winter of 19481949, in a series of campaigns starting in September, 1948.

The campaign in the Liaoning Province, southernmost of the Manchurian provinces and about 150 miles northeast of Beiping [fn] took place from September 12 to

\footnotetext{
${ }^{12}$ This followed the dissolution of the wartime CBI - China, Burma, India - theater of operations upon the recall of Lieutenant General Joseph W. Stilwell, USA, following Stilwell's break with Chiang Kai-shek, largely over the issue of corruption within the officer corps of Chiang's army.

${ }^{13}$ Dean Acheson, Present at the Creation: My Years in the State Department. New York, W.W. Norton \& Company, 1969, page 203.

14 “The United States Marines in North China 1945-1949,” by Henry I. Shaw, Jr., Historical Branch, G-3 Division, Headquarters U.S. Marine Corps, Washington, D.C., 1960, revised 1962, reprinted 1968, page 23. (Marine Corps Historical Reference Pamphlet; hereafter, China Marines).

${ }^{15}$ Barr, located at Nanking, was Director of the American Military Advisory Group. As fate would decree, as commander of the U.S. 7th Infantry Division, he would meet the onslaught of the Chinese Army in northeastern Korea in November-December 1950, with tragic results.

${ }^{16}$ State Department Report, page 336.

${ }^{17}$ Quoted in Samuel B. Griffith, Sun Tzu/The Art of War, Oxford University Press, paperback edition, 1963, 1975, Chapter III, “Offensive Strategy,” p. 77.
} 
November 2, 1948. By its conclusion the Communist army had absorbed many Chinese Nationalist units including two army corps which had been equipped by the U.S.

During the November 1948-January 1949 series of battles which destroyed Chiang's grip north of the Yangtze River, the People's Liberation Army encircled and then took over the Chinese Nationalist 12th Army which included some of the last of the units trained by the U.S. Army during WWII.

Marshal Lin Piao's Beiping-Tientsin (Beijing-Tianjin) campaign (November 28, 1948 - January 31, 1949) sealed the fate of Chiang's regime. In the 64-day campaign Lin gathered an army numbering about 800,000 to defeat the Nationalist force of about half a million men in 50 divisions. In this campaign the PLA reportedly used a number of former Nationalist divisions that surrendered in earlier fighting. Lin's assault on Tientsin began January 14, 1949; the city surrendered January 17; on January 20 the defeated Nationalist commander agreed to evacuate Beiping and to bring his entire army of 250,000 over to the Communist side. The Chinese Red Army - the People's Liberation Army - would put on a victory parade in the old "northern capital" on February 3, 1949. ${ }^{18}$

"In a few short months," a U.S. Marine Corps historian would write, "the Communists captured vast quantities of munitions and absorbed thousands of defecting National troops who had lost all desire to fight.”

In many instances it would be claimed that it had merely been necessary for the troops to switch to new cap badges in their transition from Kuomintang soldiers to members of the Chinese Red Army. ${ }^{19}$ And in the Korean War days which lay ahead it would be noted that "many (captured Chinese Communists) were still wearing American uniforms originally supplied to Chiang Kai-shek."20

The "southern capital” (Nanking) fell to Mao’s forces on April 23, 1949. Chiang resigned the presidency (which he later reclaimed) and flew to his home village in Chekiang (Zhejiang) province. After a brief visit he boarded a ship at Shanghai and departed for Taiwan. Chiang reached this destination on May 26, 1941 and immediately set up his Republic of China "in exile".

The remnants of the Nationalist regime on the mainland dwindled to a scattering of resistants who would continue to battle the Communists for several months; for the moment the Nationalists, in addition to Formosa, also held Hainan island and the Zhoushan islands. They would be driven from these key offshore islands in May and June 1950. The Hainan and Zhoushan garrisons joined Chiang's forces on Taiwan.

On October 1, 1949 “Chairman Mao” proclaimed the People’s Republic of China.

The "new China" had more than a million men under arms. But the People's Liberation Army included - as already noted - a heavy infusion of manpower from Chiang Kai-shek's Chinese Nationalist Army.

What role would these transformed soldiers have as members of the army which Mao unleashed into North Korea during October, 1950? What influence would the exNationalist soldiers exert in the matter of splitting into two "enemy camps" the Chinese

\footnotetext{
${ }^{18}$ For an excellent account of the series of campaigns conducted by Mao's forces in 1948-49, see Dr. Larry M. Wortzel’s “The Beiping-Tianjin Campaign of 1948-49,” in Chinese Warfighting, pages 56-72.

${ }^{19}$ James L. Stokesbury, A Short History of the Korean War. New York: William Morrow and Company, 1988, p. 195 (hereafter, Stokesbury).

${ }^{20}$ Ibid., 195-196.
} 
who would becomes prisoners of the United Nations Command? Did the divisions containing large numbers of soldiers presumably not committed to the Communist cause contain the seed of discord which would find its voice in the prison compounds of Korea?

Is it possible that the impeccable wisdom of Sun Tzu - quoted above - may, in retrospect, have sown the seeds for the internecine warfare which turned the prison camps of the Korean War into a sort of renewal of China's Civil War?

In one official U.S. army history ${ }^{21}$ of the war the author points out that, "among the Chinese troops were many quondam members of the Nationalist armies of Chiang Kai-shek. During the civil war there had been wholesale desertions and surrenders and the Communists had taken the former Nationalists into their military organization en masse. Disaffection was widespread in their ranks and once they had become prisoners of the UNC, many soon demonstrated a lack of enthusiasm for a return to Communist control."

Colonel Roy Appleman ${ }^{22}$ a leading army historian who meticulously examined this issue suggests that in many of the divisions in the Chinese intervention forces perhaps 30\% of the troops were former Chinese Nationalist soldiers.

In any event, the "new China” which emerged after October 1, 1949 engendered a massive change in the U.S. attitude toward its old ally. The ascent to power of the Chinese Communists rapidly altered public opinion in the U.S. "The sympathy and inflated admiration which had existed for the wartime [WWII] ally turned to contempt and bitterness after 1949....This disillusionment was further transformed into fear when in February, 1950, the new Communist government in Peking formally allied itself with the Soviet Union."23

\section{The Decision to Intervene}

At the time of the entry of the Chinese troops into the theater of operations in North Korea many in the West regarded China as "a weak and chaotic nation”. It was barely one year since the proclamation of the People's Republic of China. Nevertheless, the "surreptitious entry of some 260,000 Chinese People's Volunteers ${ }^{24}$ across the Yalu into North Korea was a spectacular military deception” ${ }^{\text {, } 5}$ and also a remarkable military achievement.

The Korean War had started on June 25, 1950 when North Korean troops invaded South Korea along a broad front spanning the length of the demarcation boundary between the two countries. After the Japanese were ousted from Korea at the end of WWII, this line had been established at the 38th Parallel as a temporary dividing line. It

\footnotetext{
${ }^{21}$ Walter G. Hermes, Truce Tent and Fighting Front. Washington: Office of the Chief of Military History, Department of the Army, 1966. (United States Army in the Korean War series), p. 136. (Hereafter, Truce Tent).

${ }^{22}$ Lt. Col. Roy E. Appleman, Jr., Disaster in Korea: the Chinese Confront MacArthur. College Station: Texas A\&M Press, 1989, p. 441. (Hereafter, Disaster).

${ }^{23}$ Richard H. Solomon, A Revolution Is Not a Dinner Party. A Feast of the Images of the Maoist Transformation of China. New York: Anchor Press.Doubleday, 1978. Page 25.

${ }^{24}$ The official name given to the intervention force by Beijing was Chinese People's Volunteer Force. The name used by the U.S. military - and the form used in this essay - is "Chinese Communist Forces" or "CCF".

${ }^{25}$ Warfighting, p. 10. See the excellent essay, "Introduction: Patterns of PLA Warfighting” co-authored by Ryan, Finkelstein and McDevitt, 3-22.
} 
was designed to keep apart Soviet Union troops and U.S. troops advancing toward each other from the north and south. It had become de facto a national boundary.

It is not the purpose of this essay to relate the series of events, military and diplomatic which led to intervention by the United States acting for the United Nations. In what turned out to be a cruel understatement President Harry S. Truman initially called it a "police action" - words that would come back to haunt him. ${ }^{26}$

The Chinese leadership seems to have been taken aback by the vigor of the U.S. response. Shu Guang Zhang, a professor of international relations at the University of Maryland, writes that, "just a few days after the outbreak of the Korean conflict...Beijing began to make military preparations for a possible engagement." ${ }^{27}$ He chronicles the steps taken by Mao to put together the command structure for an expeditionary force.

Almost immediately Soviet Premier Josef Stalin was sounded out to determine the interests of the USSR and, more importantly, to gauge the support (in aircraft, weapons and other military supplies) which might be expected from the Russians if China went to the aid of Kim Il Sung and the North Korean Communist state.

Mao also began to orchestrate the redeployment of the People's Liberation Army for possible commitment to combat in Korea. The formidable Fourth Field Army's XIII Army Group would be the first to change its location as the 38th, 39th and 40th Armies (a Chinese "Army" being somewhat similar in design and role to a U.S. corps) shifted to positions north of the Yalu, the river boundary between Manchuria and North Korea. The XIII Army Group would be strengthened with an additional Army and three artillery divisions. ${ }^{28}$ The move took place in mid-July when the U.S. forces were being battered by onrushing North Korean columns. During this period Mao was forced to make many changes in the Chinese command structure so that in many cases commanders found themselves taking over units with which they were not familiar.

Jung Chang and Jon Halliday, recent biographers of Mao, make the interesting claim that "Kim wanted Chinese troops kept out until they were absolutely needed. Stalin, too, wanted them in only when America committed large numbers of troops for the Chinese to 'consume'."29 By August 29 Kim was sending "help!” signals to Stalin. He felt that he now needed assistance from China. It is generally agreed that it was not until October 1 - on the first anniversary of the People's Republic of China - that Mao was given the go-ahead by Stalin.

The Chinese forces were ready. Designated as "Chinese Volunteer Forces" so as to muddy the nationality issue that might have created the need for a declaration of war by the Chinese government, the PLA was able to unleash six infantry armies with three artillery divisions ${ }^{30}$ into battle in the Korean theater of operations with significant competence.

\footnotetext{
${ }^{26}$ It is hard to establish exactly when Truman used these words - ostensibly to get around needing to ask Congress for a declaration of war. David McCullough's Truman, p. 789, notes that “Truman [believed] that to appeal to Congress would make it more difficult for future presidents to deal with emergencies.” Truman also would note that in its role the U.S. was acting as agent for the United Nations.

${ }^{27}$ Warfighting, Chapter 5, p. 91.

${ }^{28}$ Ibid., p. 9.

29 Jung Chang and Jon Halliday, Mao: The Unknown Story. New York: Alfred A. Knopf, 2005, p. 361.

${ }^{30}$ Approximately 250,000-275,000 soldiers during the period October 19-November 5, 1950.
} 
The intervention of the Chinese military forces under the command of Marshal Peng Dehuai - not the redoubtable Lin Piao ${ }^{31}$ as has been written in several accounts of the Korean War - had an immediate and incontrovertible impact upon the battlefield. It is not necessary for our purpose to elaborate on the series of battles in November-December 1950, the defeat inflicted on the United Nations Command, the downfall and eventual dismissal of General Douglas MacArthur, and the gradual shift away from offensive operations to the protracted defensive struggle from lines of trenches and fortress-like hilltops which virtually spanned the width of the Korean peninsula. Suffice to say that Mao's forces soon took over the war against the United Nations Command, that Peng would head-up the enemy's joint command and that the ratio of Chinese to North Korean combatants rose to 6:1. The Chinese took charge of the battlefield and would, subsequently, also exert the predominant leadership on the Communist side at the negotiations table.

\section{The Chinese Prisoners}

A momentous meeting took place on remote Wake Island in the mid-Pacific on October 15, 1950 - just one month after the spectacular U.S. amphibious landing at Inch'on, the victory which started Eighth Army on its northward drive. General MacArthur and President Truman met ostensibly to discuss the "final phase" of the UN campaign in Korea. At this meeting MacArthur assured Truman that the chances of Chinese intervention in Korea were negligible. Truman left the meeting relieved that the situation appeared to be well in hand. The "historic meeting" lasted only 56 minutes.

On the battlefield fragmentary reports begin to filter back which would tell an uneasy story. On October 25, near Unsan in North Korea, the Republic of Korea (ROK) 1st Division captured three Chinese soldiers. They would be the first Chinese POWs taken by UN troops. But for the moment G-2 (intelligence) regarded them as itinerant volunteers who crossed the border to engage in guerrilla warfare.

Four days later - to the east where U.S. X Corps was operating independently of Eighth Army - the ROK 3d Division captured 16 Chinese soldiers who readily told interrogators they came from Manchuria and had crossed the Yalu undetected two weeks earlier. They identified a division of the 42d Army which had in July been added to the XIII Army Group. The Marines reported taking a prisoner from the Chinese 124th Division and learned that the 125th Division was also present in the area.

The brief but successful Chinese "1st Phase Offensive" lasted just under two weeks (October 25 through November 8) and it momentarily challenged the rapidlymoving UNC offensive. Chinese forces sprang a trap on the ROK 7th Regiment at Onjang; Eighth Army sent the 1st Cavalry Division to help the ROK 1st Division. The 8th Cavalry Regiment led the way, heading toward Unsan. But a Chinese division got there first, cut the road six miles south of Unsan and enveloped the U.S. regiment. By November 4 elements of the Chinese 39th Army had fallen on and "effectively destroyed” the U. S. 8th Cavalry Regiment.

\footnotetext{
${ }^{31}$ Although Lin Piao’s Fourth Army Group was the major ground command sent into Korea, Lin declined Mao's offer of command. It has been reported that he had advised against sending Chinese volunteers to fight against the Americans. This is discussed in Disaster in Korea: the Chinese Confront MacArthur. Lt. Col. Roy E. Appleman, Jr., College Station: Texas A\&M Press, 1989, pages 10-14. Appleman uses the spelling P'eng Te-huai for the Chinese field commander identified as Peng Dehuai in this manuscript.
} 
After the 1st Phase Offensive the Chinese broke off contact with the UNC forces and faded away into the mountains and forests. MacArthur's G-2 concluded that they had taken to their heels and probably left Korea.

Historian Roy Appleman comments: "They [G-2] were so poorly informed and simultaneously so confident of their capability to overcome the Chinese who might oppose them that, on 24 November, when the Eighth Army advance began in the west, and on 27 November, when the X Corps began its advance, the UN Command expected a quick victory that would give them control of all Korea to the Chinese border - and end the war." 32

The weight of the "2d Offensive Campaign" by the CCF fell upon the UNC forces as they advanced toward the Yalu River. Again, as in the earlier campaign, the high level intelligence personnel failed to immediately take seriously the information which was being gathered in the field from the interrogation of prisoners.

On November 23 a patrol from Company K, 35th U.S. Infantry discovered a wounded Chinese soldier, the first encountered in the 25th Infantry Division zone of action. If the Chinese had indeed "melted away" they were soon back in the battlefield in great numbers and their order of battle and tactical objectives were soon being related by the growing bag of prisoners.

By November 24 there were at least 100 confirmed-as-Chinese prisoners in UN hands. It was noted that prisoners talked freely and disclosed extensive information, later proved generally correct, about the Chinese forces then in Korea. They identified the six Chinese armies already on the move to make contact. ${ }^{33}$

It was soon deduced that the IX Army Group of the Chinese Third Field Army which deployed by rail from Shantung Province to the North Korean border had completed its move into North Korea bringing the 20th, 26th and 27th armies each with four divisions instead of the customary three. IX Army Group fielded a total of 12 divisions. ${ }^{34}$ By mid-November, 30 or 31 Chinese divisions plus support troops were in Korea - upwards of 260,000 Chinese soldiers on the ground with many more on the far side of the Yalu ready to enter the battle when and if needed. ${ }^{35}$

Even as UNC forces reeled back, frequently in disorder in the face of fierce "human wave" attacks, Chinese prisoners of war provided incontrovertible evidence of the Chinese presence on the battlefield. There was no longer any doubt that undeniably Chinese soldiers were being received at the prisoner holding area in Pusan and that wounded Chinese were being logged into the army field hospital at Pusan which was designated exclusively for the care of POWs. ${ }^{36}$

Prisoners continued to provide the pieces to the mosaic which would depict the magnitude of the CCF intervention. On the second day of the Eighth Army offensive, November 25, the ROK 1st Division would capture Chinese army captain Lui Ping Chang, a regimental operations officer, 197th Division, 66th Army. Lui revealed that his unit crossed the Yalu on October 24. They had moved south stealthily via mountain trails

\footnotetext{
${ }^{32}$ Disaster, p. 25.

${ }^{33}$ South to the Naktong, 751.

${ }^{34}$ Warfighting, 14.

${ }^{35}$ Disaster,p. 14

${ }^{36}$ Stanley Weintraub, War in the Wards. Korea's Unknown Battle in a Prisoner-of-War Camp. San Rafael: Presidio Press, 1976, chronicles a U.S. army medic's experiences with the 64th Field Hospital. (Hereafter, War in the Wards).
} 
as the 66th Army concentrated north of Taechon to wait in position there until UN forces walked into their trap. Their mission - was to interdict the Americans, to cut them off, surround them and annihilate them. Captain Lui, however, decided to desert. Information he furnished proved to be "remarkably accurate". ${ }^{37}$

On November 25, Chinese prisoners were seized near "Chinaman's Hat", a conical shaped terrain feature shown on the maps as Hill 329. The same day, the U.S. 52d Field Artillery Battalion supporting the 24th Infantry Division captured two Chinese soldiers. On November 26, again near Chinaman's Hat, U.S. troops captured We Yu Shu, cultural officer of Heavy Weapons Company, 2d Battalion, 359th Regiment, and 120th Division.

We Yu Shu told how his regiment had made its march south in the dark, via mountain trails across country. They were, he said, thoroughly trained in night movement and warfare. Their strategy was to minimize use of rifles, to get close so as to be able to effectively use grenades.

Also captured on the same night, Captain Chang Han-chung, commanding 6th Company, 2d Battalion, 359th Regiment, related that he had been a Nationalist soldier until 1948 when he was captured and "incorporated into" the PLA. He provided a description of the CCF system of communication in the 120th Division - which helped to explain the rapidly circulating reports of the baffling array of sounds and noises which accompanied an attack by CCF units.

According to Captain Chang couriers were utilized at all levels; radio at regimental level and up; telephone (when wire could be laid) and signal flares at battalion level; bugle at company level; whistles at platoon level. ${ }^{38}$

With some chagrin it was learned from CCF prisoners taken by the U.S. 2d Infantry Division in December that the Chinese preferred to fight American [as opposed to other UN non-Korean troops] "because they abandoned so much usable equipment during retreats, including personal clothing, weapons and many luxury items." ${ }^{39}$

It would also be learned that few Chinese soldiers were particularly concerned with the fate of the North Koreans; but many of them did believe quite seriously that if the U.S. was successful in Korea it was sure to invade China and to seek to restore the Chinese Nationalist government.

On Christmas Eve as the CCF continued to close with Eighth Army forces in the west and U.S. X Corps in the east, Chinese prisoners were taken on the Imjin River and the ROK 11th Regiment captured ten Chinese in their sector. Prisoners continued to provide information which gave interrogators a vivid picture of the large-scale Chinese operations in Korea which had become, indeed, a nightmare for U.S. commanders.

The New Year (1951) started with Eighth Army - now under the command of Lieutenant General Matthew B. Ridgway - bracing itself for an anticipated continuation of the attack by the Chinese and North Korean forces. Ridgway had taken over command on December $26 .{ }^{40}$ In addition to the ROK forces Ridgway also commanded X Corps which was stripped of its "independent" status and now came under Eighth Army control.

${ }^{37}$ Disaster, 65.

${ }^{38}$ Disaster, 178.

${ }^{39}$ Ibid., 430, cites 2d Infantry Division G-2 Journal.

${ }^{40}$ His predecessor, Lieutenant General Walton H. Walker, USA, died in a vehicular accident south of Uijongbu on December 23, 1950. 
Fifteen nations now had representation in the United Nations Command giving Ridgway a total of about 365,000 troops. The frontline was more or less along the trace of the 38th Parallel. The enemy had about 500,000 troops at the front with reserves totaling more than a million near the Yalu in Manchuria. On New Year's Eve the "3d Offensive Campaign” was launched by General Peng.

\section{The Prison Camps}

Typically, Chinese and North Korean prisoners were interrogated by intelligence officers or NCO's from the unit that captured them. In a relatively short period of time they would be sent to the Pusan area for processing. Wounded prisoners were generally held for treatment at the 64th Field Hospital which was located in the Pusan area.

A heavy influx of North Korean prisoners started to tax the initial facilities after the Inch'on landing on September 15, 1950. Four days later the Pusan Logistical Command under Brigadier General Crump Garvin became the 2d Logistical Command with responsibility for Prisoner of War facilities. Soon it was evident that 2d Log Command could not contain the growing prison population at Pusan. As the massing of prisoners at Pusan "soon imperiled logistical channels" 41 the decision was made to establish the Army's principal POW installation on Koje-do (Koje Island),off the east coast of Korea about 45 miles from Pusan.

Construction of compounds was quickly undertaken and the first transport of prisoners took place early in 1951 . Built initially to house 75,000 prisoners, with a few months there were a total of 220,000 POWs in the Koje compounds. This prison population included an estimated 21,700 Chinese.

There were four enclosures, each containing eight barbed-wire enclosed compounds holding 800-1200 POWs. In addition to the Koje-do population between 7,000 and 10,000 (at any given time) remained at Pusan, mostly in the prison hospital. ${ }^{42}$

Upon arrival at Koje, the Chinese prisoners of war were separated from the North Koreans. The Chinese were housed principally in Compounds 72 and 86. Later Compound 602 would be established as the destination for Chinese POWs who expressed the wish to return to the PRC. This segregation was done to insulate them from conflict with the growing population of Chinese POWs who did not want to return to mainland China and were identifying themselves with the Chinese Nationalist cause. Thus, what soon came about was the poison pill which would characterize the bitter reality of life in the prison camps - the fratricidal split between Communist and anti-Communist Chinese prisoners.

Early-on it became evident that a new dynamic was at work. Normally POWs directed their energies toward staying alive in order to get back home after the cessation of hostilities. It was anticipated that when the opportunity presented itself all Communist prisoners of war would be exchanged for all United Nations prisoners (the concept of "all for all”). In early 1951 the reality started to surface - by no means did all of the Chinese prisoners wish to be returned to mainland China.

\footnotetext{
41 “The Communist War in POW Camps”; The Background of Incidents among Communist Prisoners in Korea." Headquarters United Nations and Far East Command, Military Intelligence Section, General Staff, Tokyo, Japan, 28 January 1953, 10. (Hereafter, Communist War).

${ }^{42}$ Including 700 captured Chinese who were identified as "intelligence targets". See Handling POWs, 12.
} 
"Some wanted to go home to China, some wanted to go to Taiwan, some did not know where they wanted to go and many wanted to do only whatever was necessary to survive at the hands of their fellow prisoners."43

Before long the Koje compounds were seething with a POW population split, literally, into two camps. Those who were opposed to repatriation became identified with the pro-Chinese Nationalist faction; those who favored repatriation to the People's Republic of China were reviled for their adherence to Communism. It became dangerous for members of one faction to enter the territory of the other. Under the noses of the guards - Korean soldiers and U.S. military police - rigid control of the respective factions was exercised by top Korean and Chinese leadership. There were secret meetings, clandestine instruction classes, kangaroo courts and vigilante "justice" which resulted in numerous instances of POWs being maimed, beaten, branded, and even murdered.

In the startlingly on-target novel mentioned earlier, the central character in War Trash, the Chinese junior officer named Yu Yuan, describes his arrival at a prison compound on Koje Island after many weeks in the U.S. Army hospital near Pusan:

"Once I was inside the compound, my first impression was that I had returned to the Chinese Nationalist army; everywhere I turned, I saw people wearing the sun emblem of the Nationalist Party. My heart sagged. The Americans were only guarding the entrance and wouldn't set foot in the compound. Everything in here was left in the hands of the prisoners, many of whom had served in Chiang Kai-shek's army."44

The strong pro-Communist faction played the leading role in the 1952 unrest on Koje which escalated to international news when - with the connivance of the Chinese the North Koreans lured Brigadier General Francis Dodd, USA, into one of their compounds and seized him as a hostage, much to the embarrassment of the U.S. high command.

A truly "inside story" of how the Koje-do brouhaha was orchestrated is related in a remarkable first-person accounting in Voices From the Korean War, related by Colonel Zhao Zuorui, described as "Secretary General, Chinese Communist United Front, UNC Koje-do Camp.” 45 Colonel Zhao, former political commissar, 538th Regiment, 180th Division, Sixtieth Army of the Chinese Communist Forces in Korea - the division to which Zhang Da was assigned in Korea - as was Ha Jin's protagonist in War Trash. Colonel Zhao's story is titled, “Organizing the Riots on Koje.”

Colonel Zhao says: "The compound brigade leaders, or the traitors, tried to persuade Chinese prisoners to go to Taiwan. We had to stop their efforts and bring all our men back to China.

"First, we established Communist organizations in the camp. We developed the underground CCP groups in the fall of 1951. We recruited the party members from those who had belonged to the same CPVF unit and knew each other. Each party group had six to ten party members. The group leaders called secret meetings, exchanged information, and made plans to fight against the PGs [prison guards]. There were about two thousand

\footnotetext{
43 Stokesbury, 196.

${ }^{44}$ War Trash, 63.

${ }^{45}$ Richard Peters and Xiaobing Li, Voices from the Korean War. Personal Stories of American, Korean, and Chinese Soldiers. Lexington, KY: The University of Kentucky Press, 2004 (paperback edition 2005). Hereafter, Voices.
} 
party members among the Chinese prisoners, and at least half of the party members were organized into the underground party groups....

"We also established the CCP ${ }^{46}$-sponsored mass leadership in the camp. The CCP party members made up only $20 \%$ of the Chinese prisoners. And the CCP groups and branches operated secretly. The party leaders were usually active behind the scenes. Our goal was to unite the Chinese prisoners...Finally in April 1952, after careful preparations and many discussions the "Communist United Front" (CUF) was founded and I was elected secretary general...”

April 8, acting in accordance with instructions from the United Nations Command, mandatory screening was initiated to determine who opted for return to the PRC and who wanted to go to Taiwan.

The Communists were determined to foil the UNC efforts to conduct the screening and rioting which took place on April 10 resulted in the deaths of 77 Chinese prisoners and the murder of an American guard. Meantime Compound 602, which had been set up as the "Returning Home Compound", had begun to fill with the Chinese POWs who intended to return to the PRC. (About 6,000 out of 21,700 Chinese prisoners $^{47}$ moved to Compound 602 as a result of the screening).

“On May 1," says Colonel Zhao, “our compound liaison person came back from the clinic ${ }^{48}$ and brought us an important message from the North Korean Communist leadership. The underground North Korean Workers' Party committee in the camp had decided to capture Brigadier General Francis T. Dodd, the American commander at Kojedo at one of the Korean compounds...All the members of the [Chinese CUF] committee were excited and wanted to kidnap Dodd at one of the Chinese compounds. But our Korean comrades insisted on carrying out this action themselves."49

The North Korean POWs asked the Chinese to stage a protest in the form of a hunger strike in order to create a pretense for demanding a meeting with Dodd. After Dodd's appearance the Chinese would call off the protests to lull him into thinking "he was the only person who could deal with the camp problems thus making his personal appearance very important."50

The POWs of Compound 602 did their part and held a cordial meeting with Dodd on the morning of May 6. Dodd agreed to several of their "demands" and the Chinese agreed to end their hunger strike. Dodd and his small entourage left the compound.

Colonel Zhao says, "we had accomplished our goal of luring Dodd to the compound...we made possible the successful kidnapping of Dodd by the North Korean prisoners a short time later". 51

The actual kidnapping of Dodd took place in Compound 76 at 1:30 p.m. on May 7.

\footnotetext{
${ }^{46}$ Chinese Communist Party.

47 The Army Almanac, Harrisburg, Pennsylvania: The Stackpole Company, 1959, 383.

48 The army hospital was the popular meeting place for the Communist prison camp underground.

${ }^{49}$ Voices, 251.

${ }^{50}$ Ibid., 251.

${ }^{51}$ Ibid., 253.
} 
When Dodd was released on the night of May 10 (after having been found 'guilty' in a mock trial ${ }^{52}$ conducted by the POWs) military-enforced sanity was restored but it was clear that some important changes had to be made.

By this time General Mark W. Clark was in command in Tokyo and he approved the recommendation that the Chinese prisoners be removed from Koje-do to Cheju Island, off the southern tip of Korea, in the Yellow Sea. This was accomplished in June, 1952. Two compounds were established on Cheju-do. Here, POW Camp 3 at Mosulpo (south side of the island) would house the anti-Communist faction whose adherents wanted to go to Taiwan to join Chiang Kai-shek

Camp 3a at Cheju City (northern coast) would house the Chinese who chose to be returned to the People's Republic.

It was a sensible plan. But hotheads and zealots in both camps created a series of incidents, many of them noisy, some of them bloody and all of them designed to fray the nerves of those responsible for the welfare of the prisoners. One of several critical events at Camp 3a occurred on October 1, 1952 - the third anniversary of the PRC - when a simultaneous flag-raising event took place in defiance of orders from the U.S. camp commander. When the ensuing melee could not be contained by two U.S. MP platoons the 1/35th Infantry battalion took control, but not before 56 Chinese POWs were killed, 91 wounded and 9 slightly injured.

Ironically, the problems which led to violence even at Camp 3 where the antiCommunist Chinese were housed - and until then considered a "model” POW camp were attributed to the growing fears that a "deal" was in fact underway to force them to return to mainland China. On June 21, 1953, as the details of the armistice were close to being worked-out, the non-repatriate Chinese in the Mosulpo camp staged a major protest parade replete with Chinese Nationalist songs and a waving of flags which notably did not include the U.S. flag while ROK and UN banners were prominently displayed. They refused to heed orders to disband with the result that one compound was subjected to "the inevitable” tear gas attack and the action in the other compounds subsided. ${ }^{53}$

\section{Negotiations Toward Peace}

Once the Chinese 1951 spring offensive ${ }^{54}$ sputtered and came to a halt, General Ridgway had reached the conclusion that the time was ripe to explore the possibilities for peace negotiations and his superiors up the chain of command concurred. The other side had reached similar conclusions and a meeting was arranged for at Kaesong, (the onetime capital of Korea, below the 38th Parallel 35 miles northwest of Seoul). ${ }^{55}$ The first session took place on July 8, 1951. When this site ultimately proved inhospitable the talks were moved to the location which - to this day - remains the locus of an ongoing and as yet unresolved ideological dispute - Panmunjom.

The prospects for success initially seemed favorable.

\footnotetext{
52 Both in Colonel Zhao's narrative and in Ha Jin’s novel there are vivid descriptions of a Kafka-esque "trial setting" in which 43 representatives from 17 Korean and Chinese compounds sit as jurors as the POW case against General Dodd is acted out. In the novel the general is named Bell. See Voices, 242-258; War Trash, 172-185.

53 Handling POWs, 71-81.

54 The CCF 5th Offensive was conducted in two stages; both failed.

55 Truce Tent and Fighting Front, 18.
} 
The problem of a glitch in the issue of repatriation was not immediately recognized. It was widely held that when fighting ceased it was the obligation of the power holding prisoners of war to send them home. As things turned out a relatively obscure army officer in the Pentagon was about to alter the course of events on the Korean peninsula. Although he was then a very senior brigadier general (his date of rank was March 15, 1942) Robert A. McClure, the army’s Chief of Psychological Warfare ${ }^{56}$, filled a position not especially lofty in the hierarchy. But he reported directly to the army chief of staff, General J. Lawton Collins.

McClure, then 54 years old, was no run of the mill staff officer. A regular army infantry officer - commissioned prior to WWI after service in the Philippine Constabulary - he served as a captain for 17 years before starting a rapid ascent in the early days of World War II. He earned a formidable reputation working in the field of information (and disinformation) under General Dwight D. Eisenhower. At the end of WWII, based in Germany, he controlled a vast array of newspapers, magazines and broadcast facilities. In early July, 1951, but prior to the actual start of truce talks McClure sent a paper containing his views to Collins. ${ }^{57}$ McClure's concerns found a receptive ear - and proved to have a major impact upon the formulation of U.S., indeed United Nations Command, and policy; and in a sense had an impact on the course and duration of the war.

McClure shrewdly noted enforced repatriation, if strictly enforced, would be unacceptable - even life-threatening - to the many former Chinese Nationalist soldiers in U.S. hands. Surely, he argued, these soldiers who were anti-Communist at heart probably had no wish to return to mainland China under the control of the Communists.

He reminded General Collins that many of the prisoners held by the U.S. were soldiers who had been forced to join the Communist army. ${ }^{58}$ If they were now compelled to return, he theorized, they might well be faced with heavy punishment or even execution because they had allowed themselves to be taken prisoner.

As Walter G. Hermes, an army historian points out: "McClure presented a clever, if somewhat debatable solution. The bulk of the ex-Nationalist prisoners, he argued, would probably elect to go to Taiwan if they were given a choice. Since [Taiwan] could be officially considered a part of China (emphasis added), he felt the U.S. was well justified in carrying out repatriation not to mainland China but to Taiwan.

As an additional dividend of such a policy he pointed out that ... future psychological warfare operations would gain credibility once enemy soldiers learned of this U.S. policy. Since they could be assured they would not forcibly be repatriated to a brutal regime they would be more likely to surrender.

The notion that prisoners should decide on their repatriation destination introduced a serious question. It appeared to violate the sense of the Geneva Convention ${ }^{59}$ that a prisoner was entitled to be returned to the homeland of his origin. Article 118

\footnotetext{
${ }^{56}$ After 1956 redesignated Chief of Special Warfare and the forerunner of today's Special Operations program.

${ }^{57}$ Memorandum, McClure for Chief of Staff, 5 July 1951, subj: "Policy on Repatriation of Chinese and N.K. Prisoners.” (G-3 File 383.6). Discussed in detail in Truce Tent, p. 136-137).

${ }^{58}$ Truce Tent, pp. 136-137.

${ }^{59}$ The United States was a signatory to the Geneva Convention of 1949 but had not yet actually ratified the convention when the war began.
} 
stated that, "Prisoners of War shall be released and repatriated without delay after the cessation of hostilities." 60 Certainly it had been the common practice throughout the first half of the 20th century for the combatant nations to exchange POW's at the end of a conflict.

After considerable debate in the highest councils of the army, McClure's notion made its way through the political and diplomatic process even as the peace talks started.

At the negotiating table many of the issues dividing the sides were bounced back and forth until a measure of agreement was grudgingly reached. But in the matter of prisoner repatriation the issue quickly became the major dividing line that would dominate - and protract - the discussions.

On the Communist side, Chinese and North Koreans insisted upon an "all for all" formula at the moment the cease-fire took place. Mao sent word to his negotiators at Panmunjom that with regards to "the traitors" - "not a single one is to get away!" 61

On the UN side the McClure formulation was challenged from several quarters.

One faction on the UN camp seemed willing to go along with "all for all” simply as a means of getting to the cease-fire. ROK President Syngman Rhee while he clearly did not subscribe to "all for all" pronounced himself in favor of shipping all the Chinese prisoners back to the PRC because he did not like the idea that they were sitting in the south "just eating rice"

There was even the suggestion that UN officials sought to encourage Chinese POWs to opt for return to the mainland so as to mollify the Communist negotiators and representatives of the International Red Cross.

There was also some concern that Chiang Kai-shek was not wildly enthusiastic at the prospect of receiving Chinese POWs on Taiwan. He approved their being given the option of not returning to the PRC. But, it has been noted, "Chiang apparently did not wish to risk having thousands of soldiers of unproved loyalty introduced into his armed forces."63

The idea of allowing any of the Chinese POWs go to Taiwan was anathema to the Communist side for yet another reason: a suggestion originally made by General MacArthur which surfaced again and again, was the idea that Chinese Nationalist divisions should be deployed to Korea to fight on the UN side. ${ }^{64}$

But the inescapable fact is that General McClure's “straw man” escalated to become the center piece of U.S. policy. It was espoused by Secretary of State Dean Acheson and was soon the announced policy attributed to President Truman: We will not buy an armistice by turning over human beings for slaughter or slavery. ${ }^{65}$ Perhaps the

\footnotetext{
${ }^{60}$ The Geneva Convention, 12 August 1949, relative to the Treatment of Prisoners of War (Article 118) notes also: "Each of the Detaining Powers shall itself establish and execute without delay a plan of repatriation in conformity with the principle laid down in the foregoing paragraph" (cited in text).

${ }^{61}$ Mao, 368.

${ }^{62}$ Goulding, 590.

${ }^{63} \mathrm{Ibid}, 590$.

${ }^{64}$ This was vigorously opposed by President Truman and his secretary of state, Dean Acheson. It was also opposed by Great Britain, our major non-Korean ally in the UNC; Britain had already "recognized" the People's Republic, though the U.S. had not.

${ }^{65}$ Quoted in David McCullough, Truman. New York: Simon \& Schuster, 1992. However McCullough does not cite the origin of the comment as attributed to Truman. Page 872.
} 
president remembered - or was reminded - of the widespread dissatisfaction when the WWII Allies repatriated thousands of unwilling Russians (mostly ex-Red Army soldiers captured while fighting in the German ranks). Most of these returnees were promptly liquidated by Stalin or shipped off to the gulags.

Truman directed the Joint Chiefs to tell General Clark to present the U.S. views on involuntary repatriation "with the utmost firmness and without subsequent debate". ${ }^{6}$ On October 8 the Communists declared the proposals unacceptable and a recess was called.

In the months followed little progress was made toward a cease-fire, combat operations were resumed - albeit on a limited scale - positions hardened and casualty lists grew.

March 5, 1953, the world learned of Josef Stalin's death. The new masters in the Kremlin wanted an end to the war in Korea and soon signal made the rounds that the parties would come back to the negotiating tent at Panmunjom. To the great surprise of the UNC the Communists rather quickly agreed to the exchange of sick and wounded prisoners. They continued to bicker over the details of enforced repatriation until - almost inexplicably - the Communists agreed to a cease fire with those who opted not to return (i.e., to mainland China) to be transferred to the custody of a neutral party which would then supervise a final entreaty by the non-repatriate's home of origin. With this agreement, nearly 24 months after the first discussions, the signing of the armistice agreement took place at Panmunjom on July 27, 1953.

It is estimated that the UNC sustained 125,000 casualties (killed, wounded and MIA) and the Communist side suffered over a quarter of a million men - killed, wounded and captured - according to Eighth Army estimates ${ }^{67}$ - while the talks were going on.

On July 25, 1953 - as the finishing touches were being put to the Panmunjom paperwork - a Chinese two-battalion attack slammed against outposts held by the 1st Marine Division in front of the main line of resistance. "The senseless and bloody assault against the outpost came six days after the armistice terms were agreed on by both sides and during the 'twilight period' when [the parties] were working out boundaries and other details.",68

In the end, the army historian Walter Hermes offers the possible conclusion that in safeguarding the "rights" of prisoners of war who did not wish to be repatriated, the U.S. and United Nations Command had taken a "humanitarian approach" but one that had been costly in terms of casualties sustained. This approach, he contends, raises a complicated issue as to the propriety of safeguarding the rights of prisoners of war at the expense of troops in action on the fighting lines. ${ }^{69}$

Whether or not this is a justifiable conclusion is certainly something to think about. It raises to a strategic level the value of regarding the "human rights" of enemy prisoners of war who our side wishes to "protect" from repatriation to a brutal regime.

\footnotetext{
66 JCS 919368 to CINCFE, September 25, 1952.

${ }^{67}$ Truce Tent, 500-01; 7,140 U.S. service members were prisoners of the Chinese and North Koreans. Of this number 2,701 died in captivity and 4,418 returned home; 21 U.S. soldiers chose not to be repatriated. Source for POW data: Army Almanac, 383.

${ }^{68}$ Bruce Jacobs, Korea’s Heroes, New York: Berkeley Book, 1961, 180.

${ }^{69}$ Truce Tent, 500-01.
} 
But it also raises interesting moral issues and, inevitably, opens the "liberating" power to charges of brain washing and coercion.

Looking back to the 1950's we are reminded that in the conventional training of U.S. soldiers of that era, the discussion of prisoners of war - if any at all - was largely limited to the conduct expected of a U.S. soldier who had the misfortune to become a prisoner of war. Only later did the U.S. services put increased emphasis upon prisoner resistance, escape and evasion training, and - eventually - a code of conduct which described what was expected of an American in enemy hands.

In War Trash the Chinese prisoner Yu Yuan describes a prescient moment when a Chinese Nationalist leader in the prison compound calls a mass meeting to consider action to be taken against a fellow prisoner who has expressed his wish to be repatriated to the PRC. He poses a question. "Brother Bai, what is the Seventh Article of the Code of Conduct of the Communist Army? how do you think they will treat you on your return...?”70

The PLA Code was known to every CCF soldier: "Never surrender. Never let yourself be taken prisoner even at the cost of your life." U.S. soldiers were given little more than the admonition that if captured, a soldier was required to give only name, rank and serial number. Little was known or said of the code of conduct which governed soldiers of the CCF. Little training time - or thought - was given to the matter of enemy prisoners who fell into our hands.

This permeated even the highest level of command. General Clark who assumed command of the Far East Command in May, 1952, on General Ridgway's departure, was but one of many who failed initially to perceive the role being played out by enemy prisoners of war in Korea. "My experience had been with old-fashioned wars," he would note, "in which prisoners were people who had to be fed, housed, clothed and guarded, nothing more. Never had I experienced a situation in which prisoners remained combatants and carried out orders smuggled to them from the enemy high command.",71

He complained that, "the one thing that nobody in Washington briefed me about, or even mentioned, was the prisoner-of-war problem." 72 He would soon learn quite a lot about the unconventional dimension of the problem. By and large the U.S. military relatively fresh from the World War II Experience - failed to perceive that in this war there were conditions that made Korea different than any other war.

The afore-mentioned Colonel Zhao, on the other hand, typifies the captured Chinese Communist soldier who fully understood - under the PLA code - his responsibility as a prisoner: "I was ready to carry on my duty in the POW camp and continue to fight the Korean War on Koje Island. It was the second front of the Korean War."73

That, we can now appreciate, is one of the major contributions of the Chinese Communist soldiers which succeeded in making the Korean War-different.

\footnotetext{
${ }^{70}$ War Trash, 103.

${ }^{71}$ Mark W. Clark, Gen., US Army (Ret.), From the Danube to the Yalu. New York: Harper \& Brothers Publishers, 1954, page 33.

${ }^{72}$ Ibid., 33.

${ }^{73}$ Voices, p. 244.
} 